\title{
Critical Drivers and Barriers of Corporate Social Responsibility in Saudi Arabia Organizations*
}

\author{
Luisa PINTO' ${ }^{1}$, Alwyia ALLUI ${ }^{2}$ \\ Received: August 01, 2020 Revised: September 20, 2020 Accepted: October 05, 2020
}

\begin{abstract}
Several studies demonstrate that Corporate Social Responsibility (CSR) is becoming a dominant issue in both research and companies' management due to stakeholders' pressure. The identification of internal and external drivers and barriers is an initial stage of the corporate social responsibility implementation. The study aims to identify and analyze the drivers and barriers of CSR in Saudi Arabia's private organizations. For this purpose, primary data were collected using a survey questionnaire that was administered to a representative sample of companies from different sectors in Saudi Arabia. The results show that the main drivers behind the adoption of CSR among Saudi companies are improvement of corporate image, ethical/moral commitment, and to some extend customers' requirements and risk management. The findings of this study also suggest that there are important barriers hindering the adoption of corporate social responsibility. Among these, the lack of management commitment and the lack of investors' interests together with the lack of economic resources and lack of employees' competencies are the most prominent. The findings of this study not only contribute to a deeper understanding of CSR drivers and barriers, but could also encourage firms' managers and stakeholders to improve CSR activities for more effective implementation.
\end{abstract}

Keywords: Corporate Social Responsibility, Private Organizations, Saudi Arabia

JEL Classification Code: L20, L60, M14, M10, M16

\section{Introduction}

The concept of Corporate Social Responsibility (CSR) has several interpretations, not clear boundaries, and has been part of the academic and business vocabulary for decades (Dahlsrud, 2008). Its potential benefits are widely known, not only its effect on economic performance, but

\footnotetext{
*Acknowledgements:

This work was supported by the research project: Corporate Social Responsibility in Saudi Organizations: Understanding Drivers, Barriers, and Benefits; Prince Sultan University; Saudi Arabia, grant number IBRP-CBA-2018-10-6.

${ }^{1}$ First Author and Corresponding Author. Assistant Professor, Management Department, Prince Sultan University, Saudi Arabia [Postal Address: Prince Sultan University - Women Campus, P.O. Box No. 66833, Rafha Street, Riyadh, 11586, Saudi Arabia] Email: Ipinto@psu.edu.sa

${ }^{2}$ Assistant Professor, Management Department, Prince Sultan University, Saudi Arabia. Email: laallui@psu.edu.sa Non-Commercial License (https://creativecommons.org/licenses/by-nc/4.0/) which permits unrestricted non-commercial use, distribution, and reproduction in any medium, provided the original work is properly cited.
}

also in reducing environmental impacts and developing the wellbeing of employees, and helps to enhance the reputation and competitive companies positioning (Crane et al., 2019; Carroll \& Shabana, 2010; Orlitzky et al., 2003).

Many scholars suggest various interpretations for CSR including the company's engagement in social initiatives that can bring long-term benefits for the community and the company and positively impact their current and prospective stakeholders (Burke \& Logsdon, 1996; Weber, 2008; Yin, 2017). Another scholar in this debate advocates that to ensure sustainability companies should include social and environmental practices as part of their strategy management of SR (Social Responsibility) activities and projects, which has been recognized as a not easy process for companies (Campbell, 2007). According to Razak (2015), the concept of CSR within the Kingdom of Saudi Arabia (KSA) is still very young compared with the evolution of the concept across the world, and there is not a clear understanding of the concept, practices, and implementation. CSR in the KSA has been viewed as a charitable activity (Maqbool, 2015). Companies are not integrating CSR as part of their strategy, due to their lack of knowledge and efforts to satisfy the general public. The lack of SR studies in developing countries including 
KSA can be a reason for that (Alotaibi et al., 2019; Khan et al., 2019).

The present study is significant at this time, not only because of the opening of Saudi markets to foreign direct investments, the problems of the low oil price and its effects, but also due to 2030 Saudi Arabia Vision. One of the visions related to corporate responsibility is that the Saudi Government aspires to have businesses not geared solely towards generating profits, but also to contribute to the development of the society and the economy at large. They expect that companies contribute to a sustainable economy through the implementation of social practices, as well as help provide to young men and women opportunities to build successful careers. The government will support companies that follow this commitment to participate to the country's development and to address national challenges. Until now, few theoretical and empirical research was done to explore the CSR practices in KSA, and research on the drivers of CSR is lacking in Middle East countries (Al-Abdin et al., 2018). The literature review conducted by the authors found that studies related to drivers for implementing CSR practices are fewer than the ones related to barriers.

The main goal of this research is to provide an illustrative picture of Saudi Arabian companies' engagement in CSR practices, understand what drives the implementation of CSR practices and what are the barriers faced in adopting those practices.

Specifically, the study attempts to answer the following questions: CSR?

-What are the drivers of Saudi companies in implementing

-What are the most significant barriers, hindering the adoption of CSR in Saudi Arabia?

The structure of this article is organized as follows: section one identifies research goals. section two reviews the literature regarding the drivers of and barriers to CSR implementation. In section three, methodology of the study is presented, followed by the analysis and discussion of results in section four. In the last section, conclusions, future research directions, and limitations of the study are presented.

\section{Literature Review}

Organizations must know what drives them and what are the challenges to implementing CSR practices. According to several researchers, the identification of internal and external drivers and barriers is the first step to CSR implementation (Aloitaibi et al., 2019; Al-Abdin et al., 2018).

Business and society are linked and are interdependent. Social responsibility is an engine of social progress, and social responsibility, in this global and changing world, is a way for companies to become more responsible as global citizens and local neighbors (Shyam, 2016). CSR has been part of the academic and business vocabulary for decades, and in the literature review, several CSR definitions were found, each of them trying to highlight different aspects of the concept and its evolution along the time. The origins of corporate social responsibility go as far back as when individuals started companies and employing labor. The expression CSR was coined in 1953 with the publication of the book Social Responsibilities of the Businessmen by Howard Bowen. During the 70s and 80s, academic discussion of the concept of CSR grew. Drucker (1984) wrote how it is important and imperative to turn social problems into economic opportunities. Ben and Jerry in 1989 was the first company to publish a social report, and the first larger company was Shell in 1998 (Carroll, 1999).

There are several definitions of CSR. The one adopted in this study, and the most widely used, it is the definition formulated by the World Business Council for Sustainable Development (2000): "CSR is the continuing commitment by the business to behave ethically and contribute to economic development while improving the quality of life of the workplace and their families as well as the local community and the society at large".

For Blowfield and Frynas (2008), several definitions of CSR can be found in the literature, however they share similar principles. For example, the definition issued by the European Commission, whereby companies should interact with their stakeholders in a voluntary basis integrating social and environmental concerns in their interaction on business operations and emphasizes the environmental concerns, does not mention the economic sustainability; however, both definitions share the belief that companies have a responsibility to the stakeholders.

Carroll (1991) noted that organizations are required to fulfill four areas to achieve CSR: economic, legal, ethical, and philanthropic. Philanthropic responsibilities are related to be fair and avoid harm, to be a good corporate citizen, incorporated ethical responsibilities in business decisions, and do what is right. Legal responsibilities are related to the law which can be defined as the society's codification of right and wrong and economic responsibilities are related to profit, and it is the basis upon which all others rest. Schwartz and Carroll (2003) introduced a model based on economic, legal and ethical aspects to distinguish philanthropic ethical motives and strategic motives in implementing CSR practices. Ethical responsibilities consist of a set of practices in compliance with standards, norms, or expectations of society, which are also related to the legal responsibilities, and compliance with the laws and regulations. Economic responsibilities consist of profitability, competitiveness, and operating efficiency. This model shows that no one area is more important than the other, and they partially overlaps. Responsible corporations are those who do not meaningfully 
do anything that could harm their key stakeholders, such as their employees, investors, suppliers, customers, or the local community where they operate, and if any harm occurs, they strive to rectify (Campbell, 2007). Several definitions of CSR stated in the literature of CSR were analyzed by Dahlsrud (2008). He found that five dimensions are common in these definitions: environmental, economic, social, stakeholder, and philanthropy. However, according to Gray (2010), CSR interpretation differs in time, company location and from company to company, even in the same sector.

\subsection{Drivers and Barriers in the Implementation of CSR}

The implementation of CSR is not an easy step as it requires profound changes in organizational structures, routines, and people's behaviors. It is shaped by socio-political drivers, which are supported by bridging macro-level, sociopolitical facets of CSR with its meso-level, organizational implications (Maon et al., 2017). Organizational cultural values may either support or inhibit the adoption of CSR. For example, in an organizational culture that values the competitive environment, managers may tend to spend time and resources on the activities and processes that are linked to competitive advantage.

The drivers and barriers to CSR implementation have been the subject of several studies (e.g., Aloitabi et al., 2019; Al-Abdin et al., 2018; Arvidsson, 2010; Berman et al., 1999; Vimala \& Suresh, 2017; Jamali, 2008; Laudal, 2011; Maon et al., 2017; Shen et al., 2015; Yin, 2017; Zu \& Song, 2009). According to Yin (2017), internal and external factors, such as ethical corporate culture, management commitment, classified as internal factors and external factors, such as globalization challenges, political factors, and normative social pressures. affects how organizations act in the implementation of social practices. For Berman et al. (1999) firms implement CSR practices due to instrumental and normative approaches. The normative approach states that companies have a moral obligation to take into consideration their stakeholders' interests and the instrumental approach suggests that stakeholders perceive that CSR practices can improve the firm's financial performance. Academics, industry participants and other interested parties recognized the complexity of the drivers and barriers that affects CSR (Fabrizi et al., 2014).

Agudo-Valiente et al. (2017), in a study of Spanish firms, found that CSR barriers and drivers can be classified as those that are influenced by managers' moral beliefs and those which are not influenced by such beliefs; they are classified accordingly as subjective and objective. The objective drivers mostly mentioned by managers are: stakeholder pressure, institutional framework, and reputation management, and subjective drivers are the implementation of sustainable development principles and ethical integration in firms' daily activities. Regarding the barriers, the subjective ones perceived by managers are: philanthropy, charity and public relations, while the objective CSR barriers are financial availability, human resources and time to implement CSR practices. They also found that CSR depends on firms' sizes and sectors. In small firms, the involvement in CSR practices is lower than in larger firms due that the conception of CSR is more limited for managers of small companies and their firms tend to present more barriers. The higher involvement for CSR can be explained by the fact that managers of larger firms have a broader conception of CSR.

According to Bocquet et al. (2017) firms implement CSR practices to benefit in maintaining and building a strong reputation; attracting new customers; attracting and retaining the best employees; and fostering innovation (product, process, environmental, social innovations, etc.). In the European Survey on CSR, the most prevailing driving forces for implementing CSR initiatives were ethical/moral commitment; top management prioritization; risk management; and market positioning (Arlbjørn et al., 2008).

In Arevalo and Aravind's (2011) study made in the Indian industry, strategic reasons, such as profits, brand reputation, and stakeholder satisfaction, are important drivers for CSR. However, they conclude that the main motivators for CSR implementation are managers' moral values and business ethics. Another study found that CSR drivers depend on the company, industry, and country where firms are located (Orlitzky et al., 2017). Laudal (2011) analyzed the drivers and barriers of CSR in the Norwegian clothing sector. He compared CSR implementation among small- and mediumsize enterprises and multinational enterprises, and showed that according to different business contexts and firm size, drivers, such as reputation sensitive to local stakeholders, risk, conformity, reputation, autonomy, and barriers such as capacity cost/ benefit ratio, risk external control, and risk internal control may vary. Sweeney (2007) explored opportunities and barriers of CSR in Irish companies using semi-structured interviews. He found out that the only barrier perceived by small- and medium-size firms was financial constraints. Valmohammadi (2011) revealed that in Iran, CSR practices are not considered in the business context, and the main drivers for CSR are quality enhancement, customer loyalty and environmental preservation.

A study made in the United Arab Emirates (UAE), concluded that the most important driver for implementing CSR is environmental preservation, followed by improving brand reputation, developing healthy relationships with the government sector, increasing productivity and enhancing employees' loyalty. A fifth of responding organizations reported that they implement CSR to comply with Zakat, 
the Islamic values and practices (Dubai Chamber, 2009). Waris et al. (2017) found that firms in developed countries, in contrast with firms in developing countries, perceive more pressure from the public for CSR practices, which suggests that the public in developing countries requires awareness programs highlighting social and environmental issues due to their lack of knowledge and information.

In the European Survey on CSR, the most often mentioned barriers were: suppliers, due to the existence of many suppliers for CSR control, lack of human resources and lack of power toward the suppliers. One barrier which might explain the low priority seems to be the need for more competency, staff knowledge, experience, and/or authority (Arlbjørn et al., 2008). In a report launched by the Sustainability Advisory Group in 2009, entitled What Do Middle Eastern Leaders Think about CSR, the barriers identified to CSR implementation were: lack of government requirements and incentives and responsibilities of CSR actions with $45 \%$ of answers, the difficult to secure funding for CSR and other priorities at the time were identified as other barriers too. The results of a study made in 2009, to evaluate the state of CSR in UAE, indicated that the key barriers in implementing CSR are: lack of knowledge and awareness for CSR and the inability to accommodate the CSR function. The three main barriers are followed by lack of resources and perceived high cost of CSR projects. Other barriers to CSR include lack of government support, top management commitment, CSR results not visible, time constraint, and employee's resistance to CSR implementation (Dubai Chamber, 2009).

Aloitabi et al. (2019), in a study to investigate the barriers to CSR in KSA, identified seven barriers through a comprehensive literature review, interviews with experts, and in more detail using a questionnaire survey: additional costs, lack of awareness and knowledge, lack of guidelines and coherent strategy, lack of stakeholder communication, lack of law enforcement, lack of training, and unclear project requirements. Arevalo and Aravind (2011) found that the most significant obstacles, for Indian companies are lack of resources, mainly for CSR training, the difficulty of implementing CSR, and lack of top and middle management support and knowledge, and difficulty in obtaining information about CSR practices and implementation.

An extensive literature review made by Shen et al. (2015) identified twelve barriers for CSR: lack of stakeholder awareness, lack of training, lack of information, lack of financial resources, lack of customer awareness, lack of their reputation value, lack of knowledge, lack of regulations and standards, diversity, company culture, lack of social audit, and lack of top management commitment. Results from their empirical study show that financial constraints are the main barrier to CSR implementation in the Indian textile sector, follow by customer awareness, lack of regulations and standards, and lack of top management support are vital in the implementation of CSR, which are considered, by the authors, as the most common in developing nations. Vimala and Suresh (2017) in their research regarding the drivers and barriers of CSR in developed and developing economies, found that the interpretation of drivers and barriers to implementation of CSR differs according to the business, culture, and society in which the corporation is situated. They also found that drivers and barriers of CSR depend on strategic versus moral motives and firms' size.

On the basis of the literature review, Table 1 presents the drivers and barriers consider in this research.

Table 1: Drivers and Barriers of CSR

\begin{tabular}{|c|c|c|c|}
\hline Drivers & Authors & Barriers & Authors \\
\hline $\begin{array}{l}\text { Requirements from } \\
\text { top management; } \\
\text { Requirements from } \\
\text { investors; Requirements } \\
\text { from customers; Improve } \\
\text { organizational performance; } \\
\text { To innovate; Risk } \\
\text { management; Ethical/moral } \\
\text { commitment; Improvement } \\
\text { of corporate image } \\
\text { Islamic Religion; Charity; } \\
\text { Attention from community } \\
\text { groups }\end{array}$ & $\begin{array}{l}\text { Arevalo and Aravind (2011); } \\
\text { Arlbjørn et al., 2008); } \\
\text { Bocquet et al.,(2017); Yin } \\
\text { (2017); Aloitabi et al.(2019) } \\
\text {; Al-Abdin et al.(2018); } \\
\text { Arvidsson (2010); Berman } \\
\text { et al. (1999); Vimala and } \\
\text { Suresh (2017); Jamali } \\
\text { (2008); Laudal, 2011; Maon } \\
\text { et al., 2017; Zu \& Song } \\
\text { (2009); Agudo-Valiente et } \\
\text { al. (2017), Orlitzky et al. } \\
\text { (2017); Sweeney (2007); } \\
\text { Valmohammadi (2011); } \\
\text { Dubai Chamber,( 2009). }\end{array}$ & $\begin{array}{l}\text { Lack of human resources; } \\
\text { Lack of economic resources; } \\
\text { Lack of government } \\
\text { requirements and incentives; } \\
\text { Lack of management } \\
\text { commitment; The suppliers, } \\
\text { in general, are not ready for } \\
\text { CSR; Our company is not } \\
\text { important enough for the } \\
\text { supplier (lack of power); We } \\
\text { have other priorities at the } \\
\text { moment; Our company is too } \\
\text { small }\end{array}$ & $\begin{array}{l}\text { Arevalo and Aravind (2011), } \\
\text { Arlbjørn et al. (2008); } \\
\text { Bocquet et al. (2017); } \\
\text { Al-Abdin et al. (2018); } \\
\text { Arvidsson (2010); Berman } \\
\text { et al. (1999); Vimala and } \\
\text { Suresh (2017); Jamali } \\
\text { (2008); Laudal, 2011; Maon } \\
\text { et al., (2017); Zu \& Song } \\
\text { (2009); Agudo-Valiente et } \\
\text { al. (2017), Orlitzky et al. } \\
\text { (2017); Sweeney (2007); } \\
\text { Valmohammadi (2011); } \\
\text { Dubai Chamber (2009). }\end{array}$ \\
\hline
\end{tabular}




\section{Research Method}

This research was based on a questionnaire to identify the motivations and barriers of CSR practices. The questionnaire was designed based on the drivers and barriers of CSR, as defined in the above-mentioned literature. The first step was to validate the survey by doing a pre-test in six companies from different sectors. The questionnaire was sent by e-mail or hand-delivered personally to senior executives, explaining, and justifying its main objectives. Based on the results of this pre-test, some questions were removed, and others were rewritten, according to suggestions made by companies that participated in the pre-test to provide additional clarity to the questions and to suit the Saudi Arabian context. The main goal of this first stage was to identify possible difficulties with the interpretation of the questionnaire and to eliminate or reformulate unanswerable questions.

The questionnaire contains both closed and open-ended questions and is comprised of two sections and thirteen questions. The first section provides the demographic information of the study according to the business sector, number of employees, gender, age, and job title of the manager that reply to the survey and if the company is certified. This type of information is both useful and necessary to establish relationships. Companies surveyed were categorized based on the responses to this first section. The second section intended to investigate code of conduct implementation, management certified systems adoption, and CSR key drivers, and barriers. For the drivers, different options were given to the respondents to select the appropriate ones and rank them using a five-point Likert scale, ranging from: (1) not important (1), slightly important (2), moderate important (3), important (4) to most important (5). This question was intended to investigate the key drivers that motivate organizations to adopt CSR practices. The question related to the barriers has a similar structure, different options of barriers were given to the respondents, who indicated the most suitable and ranked them. The objective of this question was to study the main challenges and determine which ones are more restrictive.

The list of companies from different sectors was selected randomly from a list of companies provided by a governmental agency, the Riyadh Chamber of Commerce and Industry. After format and wording revisions, surveys were prepared in Google forms, sent by e-mail or delivered personally, along with a cover letter describing the objectives of the research. The questionnaire was filled by 136 companies, only 94 have been validated, giving a response rate of $69 \%$. In a way, this was a convenience sampling for a developing country at this stage where there are many difficulties in data collection. Once the information was collected, the next step consisted of the analysis and interpretation of data. The collected data were numerically coded and analyzed by frequency, mean and standard deviation scores and inferential statistics with the use of the SPSS 25 (Statistical Package for the Social Sciences) software.

\section{Results and Discussion}

\subsection{Profile of the companies}

The respondent firms varied in size, as shown in Table 2 below. The majority of the firms surveyed $(62.8 \%)$ are large companies with more than 500 employees, $20.2 \%$ between 100 and 500 , and $17 \%$ of the companies have less than 100 workers. From the companies studied, $77.7 \%$ were from the service sector and $22.3 \%$ from the manufacturing sector.

It is interesting to observe that $67 \%$ of the respondents were female and $33 \%$ male, with ages between 25 and more than 56. Most of the respondents were between 26 and 35 years old (45.7\%), 19.1\% more than 20 and less than 25 , $30.8 \%$ between 36 and 55 , and $4.3 \%$ more than 56 years old (see Table 3).

The respondents were asked whether they have a code of conduct or not. Almost all companies publish a public code of conduct, with $90.4 \%$ of the companies answering yes, and $9.6 \%$ answering no. This is in line with the results of Welford and Frost (2005), who finds that a code of ethics is more common among large Asian companies than large North American or European companies.

As shown in Table 4, 47.9\% of the companies surveyed have a quality management certified system (ISO9001), $14.9 \%$ are certified by ISO $14001,15.9 \%$ by OSHAS 18001 , and only four companies (4.26\%) are certified by SA8001. This shows that Saudi companies have become aware of the importance of producing quality products and services for the national and international marketplace to maintain stringent quality requirements on imported products (Graafland \& Zang, 2014), however environmental and social certifications are less common.

Table 2: Sample distribution by number of employees

\begin{tabular}{|l|c|c|}
\hline Number of employees & Frequency & $\%$ \\
\hline Less than 100 & 16 & 17.0 \\
\hline More than 100 and less than 500 & 19 & 20.9 \\
\hline More than 500 & 59 & 62.8 \\
\hline
\end{tabular}

Table 3: Sample distribution by the respondent's age

\begin{tabular}{|l|c|c|}
\hline Respondent's Age & Frequency & $\%$ \\
\hline $20-25$ & 18 & 19.1 \\
\hline $26-35$ & 43 & 45.7 \\
\hline $36-45$ & 18 & 19.1 \\
\hline $46-56$ & 11 & 11.7 \\
\hline More than 56 & 4 & 4.3 \\
\hline
\end{tabular}


Table 4: Sample distribution by management certified systems

\begin{tabular}{|l|c|c|}
\hline Certification systems & Frequency & $\%$ \\
\hline ISO 9001 & 45 & 19.1 \\
\hline ISO14001 & 14 & 45.7 \\
\hline OHSAS 18001 & 15 & 19.1 \\
\hline SA 8001 & 4 & 11.7 \\
\hline No certified system & 16 & 4.3 \\
\hline
\end{tabular}

\subsection{Drivers and Barriers of CSR}

To better understand the drivers and barriers of CSR, the mean values and the standard deviation were calculated and are presented in the following topics.

\subsubsection{Drivers of CSR}

When looking at the drivers for implementing CSR (see Table 5) it becomes clear that the mean scores assigned by the respondents provide an indication of the most common drivers of CSR adoption. The results indicate that providing an excellent corporate image for the market is the most important driver to $\mathrm{CSR}$ ( mean $=4.12 ; \mathrm{SD}=1.22$ ), followed by the ethical $/$ moral commitment (mean $=4.09$; $\mathrm{SD}=$ 1.33). Customers' requirements and risk management was considered the third most important drivers to CSR. The lowest values obtained were: attention for community groups $($ mean $=3.36 ; \mathrm{SD}=1.46)$, philanthropy/charity $($ mean $=$ $3.41 ; \mathrm{SD}=1.32)$, requirements from investors (mean $=3.63$; $\mathrm{SD}=1.45)$, requirements from top management $($ mean $=$ 3.64; $\mathrm{SD}=1.49$ ).

To investigate whether the drivers are related, a principal component analysis with varimax rotation was conducted on the 11 items according to Table 6. Factors for which the eigenvalue was greater than 1 were retained. Within these factors, we retained individual items if their loadings were greater than 0.50 . Loadings of 0.50 or greater are considered very significant (Hair et al., 2020). Items were eliminated if they did not load on any factor with a value of .50 or greater. The reliability of the analysis was ensured through the overall Kaiser-Meyer-Olkin (KMO) statistics (0.798). Bartlett's test $(p<.001)$ verified the appropriate level of correlation. Cronbach's Alpha for factors 1, 2, and 3 are all above .7. The loadings of the 11 items are shown in Table 6.

The three underlying constructs, which have been identified, are 'Innovation and performance', 'Competitive orientation' and 'Compliance with ethics, religion, and investors demands'. These factors accounted for $65.9 \%$ of the total variance. The obtained values are significant $(\mathrm{p}<.001)$, and as you can find in Table 7 , the mean difference between the three factors is significant too (Pillai's trace $=$ $.170 \mathrm{~F}(2,92)=9.442, \mathrm{p}<.001)$.
Table 5: Drivers of CSR

\begin{tabular}{|l|c|c|}
\hline Drivers & Mean & SD \\
\hline Requirements from high management & 3.64 & 1.49 \\
\hline Requirements from investors & 3.63 & 1.45 \\
\hline Requirements from customers & 3.93 & 1.25 \\
\hline Improve organizational performance & 3.68 & 1.36 \\
\hline To innovate & 3.85 & 1.39 \\
\hline Risk management & 3.91 & 1.26 \\
\hline Ethical/moral commitment & 4.09 & 1.33 \\
\hline $\begin{array}{l}\text { Improvement of corporate image } \\
\text { (market positioning) }\end{array}$ & 4.12 & 1.22 \\
\hline Attention from community groups & 3.36 & 1.46 \\
\hline Islamic requirement & 3.71 & 1.31 \\
\hline Philanthropy & 3.41 & 1.32 \\
\hline
\end{tabular}

Note: 1 - Not important 5 - Most important.

Table 6: Drivers of CSR

\begin{tabular}{|l|c|c|c|}
\hline \multirow{2}{*}{} & \multicolumn{3}{|c|}{ Loadings } \\
\cline { 2 - 4 } & $\mathbf{1}$ & $\mathbf{2}$ & $\mathbf{3}$ \\
\hline $\begin{array}{l}\text { Requirements from high } \\
\text { management }\end{array}$ & .774 & & \\
\hline Requirements from investors & & & .689 \\
\hline Requirements from customers & & .553 & \\
\hline $\begin{array}{l}\text { Improve organizational } \\
\text { performance }\end{array}$ & .818 & & \\
\hline We want to innovate & .845 & & \\
\hline Risk management & .841 & & \\
\hline Ethical/moral commitment & & & .842 \\
\hline $\begin{array}{l}\text { Improvement of corporate image } \\
\text { (market positioning) }\end{array}$ & & .686 & \\
\hline Attention from community groups & & & .756 \\
\hline Islamic requirement & & & .708 \\
\hline Philanthropy & & & .582 \\
\hline & & & \\
\hline Proportion of variance explained & 24.3 & 24.1 & 17.5 \\
\hline Reliability & .830 & .769 & .784 \\
\hline
\end{tabular}

Several insights can be drawn from the analysis of Table 6 and Table 7, which strengthens the above findings. Saudi companies seem to adopt CSR due to normative pressures, which lead firms to accept that CSR is necessary to enhance their corporate reputation in the market (Zahari et al., 2020; Lee, 2020), and therefore, focus on obtaining legitimacy and marketing benefits from their status as responsible firms to manage the risk and due to customers demand. 
Table 7: Descriptive analysis for CSR drivers

\begin{tabular}{|l|c|c|c|c|}
\hline & Mean & SD & Innovation and Performance & Competitive Orientation \\
\hline Innovation and performance & 3.77 & 1.12 & -- & \\
\hline Competitive Orientation & 4.02 & 1.00 & $.550^{* * *}$ & $.619^{* * *}$ \\
\hline $\begin{array}{l}\text { Compliance with ethics, religion and } \\
\text { investors demands' }\end{array}$ & 3.64 & .91 & $.552^{* * *}$ & \\
\hline
\end{tabular}

${ }^{*} p<.05^{* *} p<.01{ }^{* * *} p<.001$

\subsubsection{Barriers to CSR}

Regarding the barriers faced by KSA firms in implementing CSR, results reveal that the most important barrier is the lack of management commitment $($ Mean $=$ 3.36; $\mathrm{SD}=1.35$ ) followed by the lack of investors interests $($ Mean $=3.24 ; \mathrm{SD}=1.29)$, lack of economic resources and lack of employees' competencies (Mean=3.15; $\mathrm{SD}=1.32$ ). The lowest values within the barriers were the companies' size $($ Mean $=2.84, \mathrm{SD}=1.40)$, other priorities at the moment $($ Mean $=2.90, \mathrm{SD}=1.29)($ see Table 8$)$.

Lack of management commitment and lack of investors interests were the main barriers found, which are contrary to what prior studies have suggested, that suppliers are the most important barrier because they are not ready for CSR due to the existence of many suppliers for CSR control. (Sustainability Advisory Group, 2009; Arlbjørn et al., 2008; Dubai Chamber, 2009; Aloitabi et al., 2019; Arevalo \& Aravind, 2011; Shen et al., 2015). Lack of government requirements and incentives and responsibilities of CSR actions, lack of knowledge and awareness of CSR, and the incapacity to implement CSR function, which brings additional costs, are the main barriers to the implementation of CSR in the several studies found in the literature review. A reason for the findings in our study could be that, when management commitment is not present and investors are not interested in invest in CSR, top management doesn't allocate resources for CSR. Another explanation can be that in developing countries, in contrast with firms in developed countries, companies perceive less pressure from the public for CSR practices (Waris et al., 2017). Lack of economic resources to spend on CSR activities was found as the third major obstacles to move CSR forward in Saudi Arabia, which is in line with results found, where lack of resources and financial constraints were the main barriers to CSR implementation (Arevalo \& Aravind, 2011; Shen et al., 2015). The lack of employees' competencies was also one of the barriers found, which is according to Shen et al. (2015) study in which many companies lacked training and knowledge on CSR.
Table 8: Barriers to CSR implementation

\begin{tabular}{|l|c|c|}
\hline & Mean & SD \\
\hline $\begin{array}{l}\text { Lack of employees' competencies } \\
\text { for implementing CSR }\end{array}$ & 3.15 & 1.32 \\
\hline Lack of economic resources & 3.14 & 1.26 \\
\hline Lack of investors' interest in CSR & 3.24 & 1.29 \\
\hline $\begin{array}{l}\text { Our customers are not interested in } \\
\text { CSR }\end{array}$ & 3.01 & 1.20 \\
\hline $\begin{array}{l}\text { The suppliers, in general, are not } \\
\text { ready for CSR }\end{array}$ & 3.01 & 1.29 \\
\hline $\begin{array}{l}\text { Lack of management commitment } \\
\text { in CSR }\end{array}$ & 3.36 & 1.35 \\
\hline Our company is too small & 2.84 & 1.40 \\
\hline $\begin{array}{l}\text { Lack of government requirements } \\
\text { and incentives }\end{array}$ & 2.94 & 1.40 \\
\hline Other priorities at the moment & 2.90 & 1.29 \\
\hline $\begin{array}{l}\text { Systematic models and guidelines } \\
\text { for implementation of CSR are not } \\
\text { available }\end{array}$ & 2.98 & 1.32 \\
\hline
\end{tabular}

Notes: 1 - Not important 5 - Most important.

Barriers can be lowered in the medium-term. Companies leaders, top management, and investors need to understand the meaning of CSR in decision-making and strategic planning and be more aware of the importance of CSR practices on companies' performance. CSR activities enhance the importance of the CEO authentic leadership and performance of the company's members (Yang \& Kim, 2018).

The lack of investors' interest in CSR could be due to the fact that some CSR practices imply costs for the companies. The lack of economic resources and the investment costs in CSR implementation can be overcome if the government creates funding projects to support companies on CSR implementation. With Saudi Vision 2030 and the diversification of the economy, the government should provide incentives, requirements, and maybe legislation 
to support CSR in Saudi Arabia and address the socioenvironmental issues. Furthermore, employees' skills in CSR need to be improved, as it was found that there is a lack of competent employees to develop and implement systematic models for their firms. Development of workforce skills could overcome, these barriers and can create the best practices for CSR implementation. There also seems to be a need for legislation to be clearer, law enforcement and improvement in CSR awareness by the government can also help companies to implement CSR effectively.

To further understand the findings, a principal component analysis with varimax rotation was conducted, with two factors being retained. The two constructs, which have been identified, are 'Economic and legal requirements', and 'Stakeholders lack of awareness'. These factors accounted for $52.9 \%$ of the total variance. The reliability of the analysis was ensured through the overall KMO statistics $(0.738$, excellent). Bartlett's test $(p<.001)$ verified the appropriate level of correlation. Factors for which the eigenvalue was greater than 1 were retained. Within these factors, we retained individual items if their loadings were greater than 0.50 . The items with loading $<.4$ were excluded from the analysis. Cronbach's Alpha for the two factors are above .7. The loadings of the items are shown in Table 9.

The values obtained for the mean (3.1) do not have a significant difference from the mean of the Likert scale used ( $>$.5). A non-significant difference was found between the mean of the two factors $(\mathrm{t}(93)=.029, \mathrm{p}=.977)$, and the correlation is significant and positive (see Table 10).

Table 9: Barriers of CSR

\begin{tabular}{|l|c|c|}
\hline \multirow{2}{*}{} & \multicolumn{2}{|c|}{ Loadings } \\
\cline { 2 - 3 } & $\mathbf{1}$ & $\mathbf{2}$ \\
\hline $\begin{array}{l}\text { Lack of employees' competencies for } \\
\text { implementing CSR }\end{array}$ & & .742 \\
\hline Lack of economic resources & .626 & \\
\hline Lack of investors' interest in CSR & & .550 \\
\hline Our customers are not interested in CSR & & .748 \\
\hline $\begin{array}{l}\text { The suppliers, in general, are not ready } \\
\text { for CSR }\end{array}$ & & .554 \\
\hline $\begin{array}{l}\text { Lack of management commitment in } \\
\text { CSR }\end{array}$ & .607 & \\
\hline $\begin{array}{l}\text { Lack of government requirements and } \\
\text { incentives }\end{array}$ & .849 & \\
\hline $\begin{array}{l}\text { Systematic models and guidelines for } \\
\text { implementation of CSR are not readily } \\
\text { available }\end{array}$ & .571 & \\
\hline Proportion of variance explained & 30.6 & 22.4 \\
\hline Reliability & .713 & .706 \\
\hline
\end{tabular}

Table 10: Descriptive - Barriers of CSR

\begin{tabular}{|l|c|c|c|}
\hline & Mean & SD & $\begin{array}{c}\text { Stakeholders lack of } \\
\text { awareness }\end{array}$ \\
\hline $\begin{array}{l}\text { Economic and legal } \\
\text { requirements }\end{array}$ & 3.10 & .97 & -- \\
\hline
\end{tabular}

${ }^{*} p<.05^{* *} p<.01{ }^{* * *} p<.001$

The analysis conducted provided supporting evidence and stressed that the factors 'Economic and legal requirements' and 'Stakeholders lack of awareness' may be responsible for the country's disregard of CSR. As the findings suggest, companies do not have the economic resources, and governmental institutions have not provided until now adequate levels of technical assistance, training, and incentives, and have only sparingly attempted to raise CSR awareness through dedicated programs. The weak levels of employee's competencies and the weak interest of investors, customers, and suppliers also explain the reluctance of both top managers and employees towards CSR.

\section{Conclusions}

The objective of this paper was to identify and analyze the drivers and barriers of CSR practices in Saudi Arabia. The results indicate that the main drivers behind the adoption of CSR among Saudi companies are improvement of corporate image, ethical/moral commitment, and to some extend customers' requirements and risk management. The study also reveals that there are important barriers hindering the adoption of corporate social responsibility. Among these, the lack of management commitment and the lack of investors' interests together with the lack of economic resources and lack of employees' competencies are the most prominent. Improving corporate image was the main driver perceived by managers. Companies must respect the employees, the environment, and implement fair prices and respect consumers to be able to operate responsibly and ethically, to improve their corporate image and brand reputation.

One of the main barriers identified in the analysis was the lack of management commitment with CSR. Most of the firms in the study noted that the main objective of CSR implementation is to minimize the negative impacts and maximize the positive impacts on social, environmental, and economic dimensions, followed by the commitment to strong corporate governance, making sure that they are transparent, responsible and ethical. Leaders and companies' management needs to understand the meaning of corporate social responsibility in decision making and strategic planning and must design effective communication strategies.

The findings of this study have important theoretical implications for contextual reasons. First, the findings 
supplement a small research base of studies empirically examining CSR with social-cultural dimensions. By expanding studies beyond the developed, western world, the findings of this study are particularly important as contextual studies are needed to further examine how and under what conditions CSR can be implemented in different contexts. This study also has important consequences in terms of managerial recommendations and public policy support for legislation in CSR. Future studies could examine how the non- profit organizations including academic institutions, local and global NGOs are responding and increasing the societal awareness on CSR in Saudi Arabia, and offer an understanding of how the corporate sector can support the government achieve the goals of the Vision 2030 by responding to various stakeholders' concerns in their strategic vision and decisions. An interview-based qualitative study to find managers' and employees' opinions on the implementation of socially responsible practices would be a very interesting study too.

This study has several limitations. One is that the sample of the research was composed exclusively of Saudi companies. Another is that, given its structured survey design, our findings do not indicate what the responding organizations are doing, as the data is cross-sectional and does not cover overtime.

\section{References}

Agudo-Valiente, J., Ayerbe, C., \& Salvador, M. (2017). Corporate Social Responsibility Drivers and Barriers According to Managers' Perception; Evidence from Spanish Firms. Sustainability, 9(10), 1821.

Al-Abdin, A., Roy, T., \& Nicholson, D. (2018). Researching corporate social responsibility in the Middle East: the current state and future directions. Corporate Social Responsibility and Environmental Management, 25, 47-65.

Alotaibi, A., Edum-Fotwe, F., \& Price Andrew, F. (2019). Critical Barriers to Social Responsibility Implementation within MegaConstruction Projects: The Case of the Kingdom of Saudi Arabia. Sustainability, 11, 1755.

Arevalo, A., \& Aravind, D. (2011). Corporate social responsibility practices in India: Approach, drivers, and barriers. Corporate Governance International Journal of Business in Society, 11(4), 399-414.

Arlbjørn, J. S., Warming-Rasmussen, B., Liempd, D. V., \& Mikkelsen, O. S. (2008). A European Survey on Corporate Social Responsibility. White paper, University of South Denmark, Kolding, Department of Entrepreneurship and Relationship Management.

Arvidsson, S. (2010). Communication of corporate social responsibility: A study of the views of management teams in large companies. Journal of Business Ethics, 96, 339-354.
Berman, L., Wicks, C., Kotha, S., \& Jones, M. (1999). Does stakeholder orientation matter? The relationship between stakeholder management models and firm financial performance. Academy of Management Journal, 42, 488-506.

Blowfield, M., \& Frynas, J. (2005). Editorial Setting new agendas: critical perspectives. Corporate Social Responsibility in the developing world. International Affairs, 81, 499-513.

Bocquet, R., Le Bas, C., Mothe, C., \& Poussing, C. (2017). CSR, Innovation, and Firm Performance in Sluggish Growth Contexts: A Firm-Level Empirical Analysis. Journal of Business Ethics, 146, 241-254.

Burke, L., \& Logsdon, M. (1996). How corporate social responsibility pays off. Long-range planning. American Journal of Industrial and Business Management, 7(3), 495-502.

Campbell, L. (2007). Why would corporations behave in socially responsible ways? An institutional theory of corporate social responsibility. Academy of Management Journal, 32, 946-967.

Carroll, A. (1991). The pyramid of corporate social responsibility: Toward the moral management of organizational stakeholders. Business Horizons, 34(4), 39-48.

Carroll, A. (1999). Corporate Social Responsibility, Evolution of a Definitional Construct. Business \& Society, 38(3), 268-295.

Carroll, A., \& Shabana, K. (2010). The Business Case for Corporate Social Responsibility: A Review of Concepts, Research and Practice. International Journal of Management Reviews, 12(1), 85-105.

Crane, A., Matten, D., \& Spence, L. (2019). Corporate social responsibility: Readings and cases in a global context. Oxford, UK: Routledge.

Dahlsrud, A. (2008). How Corporate Social Responsibility is Defined: An Analysis of 37 Definitions. Corporate Social Responsibility and Environmental Management, 15, 1-13.

Drucker, P. (1984). The new meaning of corporate social responsibility. California Management Review, 26, 53-63.

Dubai Chamber. (2009). Corporate Social Responsibility and Corporate Governance in the United Arab Emirates. Emirates Foundation.

Fabrizi, M., Mallin, C., \& Michelon, G. (2014). The role of the CEO's personal incentives in driving corporate social responsibility. Journal of Business Ethics, 124, 311-326.

Graafland, J., \& Zhang, L. (2014). Corporate social responsibility in China: implementation and challenges. Business Ethics: A European Review. 23(1), 34-49.

Gray, R. (2010). Is accounting for sustainability actually accounting for sustainability... and how would we know? An exploration of narratives of organizations and the planet. Accounting, Organizations and Society, 35, 47-62.

Hair, J., Page, M., \& Brusnveld, N. (2020). Essentials of business research methods (4th ed.). New York, NY: Routledge - Taylor and Francis. 
Jamali, D. (2008). A Stakeholder Approach to Corporate Social Responsibility: A Fresh Perspective into Theory and Practice. Journal of Business Ethics, 82, 213-231.

Khan, A., Muttakin, M., \& Siddiqui, J. (2013). Corporate Governance and Corporate Social Responsibility Disclosures: Evidence from an Emerging Economy. Journal of Business Ethics, 114, 207-223.

Laudal, T. (2011). Drivers and barriers of CSR and the size and internationalization of firms. Social Responsibility Journal, 7, 234-256.

Lee, J. W. (2020). CSR Impact on the Firm Market Value: Evidence from Tour and Travel Companies Listed on Chinese Stock Markets. Journal of Asian Finance, Economics and Business, 7(7), 159-167. https://doi.org/10.13106/jafeb.2020.vol7. no7.159

Maon, F., Swaen, V., \& Lindgreen, A. (2017). One vision, different paths: An investigation of corporate social responsibility initiatives in Europe. Journal of Business Ethics, 143, 405-422.

Maqbool, S. (2015). An overview of programs in Saudi Arabia with reference to select organizations. International Journal of Human Resources Studies, 5, 282-289.

Orlitzky, M., Schmidt, F., \& Rynes, S. (2003). Corporate social and financial performance: A meta-analysis. Organization Studies, $24,403-441$

Razak, R. (2015). Corporate Social Responsibility Disclosure and its Determinants in Saudi Arabia., Middle-East. Journal of Science Research, 23(10), 2388-2398.

Schwartz M., \& Carroll A. (2003). Corporate Social Responsibility: A Three-Domain Approach Business. Ethics Quarterly, 13(4), 503-530.

Shen, L., Govindan, K., \& Shankar, M. (2015). Evaluation of Barriers of Corporate Social Responsibility Using an Analytical Hierarchy Process under a Fuzzy Environment-A Textile Case. Sustainability, 7, 3493-3514.

Shyam, R. (2016). An analysis of corporate social responsibility in India. International Journal of Research - Granthaalayah, 4(5), 56-64.

Sustainability Advisory Group. (2009). What Do Middle Eastern Leaders Think about CSR. Retrieved from: www. sustainabilityadvisory.net.
Sweeney, L. (2007). Corporate social responsibility in Ireland: barriers and opportunities experienced by SMEs when undertaking CSR, Corporate Governance: The International Journal of Business in Society, 7(4), 516-523.

Valmohammadi, C. (2011). Investigating corporate social responsibility practices in Iranian organizations: an ISO 26000 perspective. Business Strategy Series, 2(5), 257-263.

Vimala, G., \& Suresh, K. (2017). Exploring approaches to drivers and barriers of corporate social responsibility implementation in academic literature. EDP Sciences, 33, 1-8.

Waris, A. Jedrzej, G., \& Zeeshan, M. (2017). Determinants of Corporate Social Responsibility (CSR) Disclosure in Developed and Developing Countries: A Literature Review. Corporate Social Responsibility and Environmental Management Journal, 24, 273-294.

Weber, M. (2008). The business case for corporate social responsibility: a company-level measurement approach for CSR. European Management Journal, 26, 247-261.

Welford, R., \& Frost, S. (2006). Corporate social responsibility in Asian supply chains. Corporate Social Responsibility and Environmental Management Journal, 13(3),166-176.

World Business Council for Sustainable Development (2000). Corporate social responsibility: making good business sense. Retrieved from: http://ceads.org.ar/downloads/Making\%20 good $\% 20$ business $\% 20$ sense.pdf

Yang, H., \& Kim, Y. (2018). The Effects of Corporate Social Responsibility on Job Performance: Moderating Effects of Authentic Leadership and Meaningfulness of Work. Journal of Asian Finance, Economics and Business, 5(3), 121-132.

Yin, J. (2017). Institutional drivers for corporate social responsibility in an emerging economy: A mixed-method study of Chinese business executives. Business \& Society, 56, 672-704.

Zahari, A. R., Esa, E., RajaduraI, J., Azizan, N., \& Muhamad Tamyez, O. F. (2020). The Effect of Corporate Social Responsibility Practices on Brand Equity: An Examination of Malaysia's Top 100 Brands. Journal of Asian Finance, Economics and Business, 7(2), 271-280.

$\mathrm{Zu}$, L., \& Song, L. (2009). Determinants of managerial values on corporate social responsibility: Evidence from China. Journal of Business Ethics, 88, 105-117. 